\title{
KUNTOUTUKSEN OHJAAJAT (AMK) - OSAAJINA KUNTOUTUKSEN KOORDINOINTITEHTÄVISSÄ
}

\section{Kuntoutusprosessin ohjaukselle on tarvetta}

Kuntoutuksen yhteiskunnalliset perusteet ja kohderyhmät ovat muuttuneet ja laajentuneet 2000-luvulla. Kuntoutuksen perusteena ovat entistä useammin erilaiset sosiaaliset syyt ja ihmisen kokonaistilanteen huomiointiin liittyvät seikat. Kuntoutuksen keskeisiä tehtäviä ovat muun muassa erilaisten perheiden tukeminen, ikääntyneiden kotona asumisen ja toimintakyvyn tukeminen, osatyökykyisten työllistymisen ja työssä jatkamisen edistäminen sekä työttömien työkyvyn arviointi, kuntoutustarpeen tunnistaminen ja kuntoutukseen pääsyn varmistaminen. (Kuntoutusasiain neuvottelukunta 2015.) Haasteita kuntoutukselle tuovat myös mielenterveys- ja päihdeongelmien lisääntyminen, nuorten syrjäytyminen ja maahanmuuttajataustaisen työvoiman työkyvyn turvaaminen. Moninaistuneet kuntoutuksen kohderyhmät ja palvelut vaativat palveluiden ohjaamista ja koordinointia, jotta palveluiden tarpeessa olevat saavat vaikuttavia kuntoutuspalveluita oikea-aikaisesti.

Kuntoutuksen ohjaus ja neuvonta ovat osa yksilöllistä kuntoutusprosessia. Kuntoutusohjauksen tavoitteena on tukea kuntoutujaa ja läheisiä arjen sujumisessa, osallisuudessa ja parhaan mahdollisen työ- tai toimintakyvyn saavuttamisessa muuttuneessa elämäntilanteessa. (Kuntoutusohjausnimikkeistö 2010.) Kuntoutuksen koordinointia ja ohjaavaa kun- toutuskumppanuutta tarvitaan etenkin silloin, kun kuntoutuminen edellyttää kuntoutujalta pitkäaikaista muutosprosessia ja yhteiskunnan monen eri palvelusektorin yhteistyötä. Kuntoutusta ohjaavalta henkilöltä edellytetään kykyä toimia ohjaustyössä suunnitelmallisesti ja kuntoutujalähtöisesti sovitettaessa yhteen kuntoutustarpeita ja kuntoutusmahdollisuuksia.

Järvikoski (2013) nostaa esiin kuntoutusprosessin ohjaukseen liittyvän vastuuhenkilökysymyksen, joka on vuosien kuluessa ilmennyt kehittämisedotuksena eri kuntoutuksen sektoreilta tehdyissä selvityksissä ja tutkimuksissa. Tämä ns. kuntoutuskoordinaattori toimisi nimettynä yhdyshenkilönä sekä kuntoutujaan että kuntouttajaverkoston suuntaan. Järvikoski (2013) kuitenkin huomauttaa, ettei ratkaisua pidä etsiä kouluttamalla jokaiselle kuntoutussektorille omaa vastuuhenkilöä.

Kuntoutuminen on suunnitelmallista ja tavoitteellista yhteistyötä. Terveydenhuoltolain (L1326/2010) mukaan kuntoutussuunnitelman laatiminen ja kuntoutusyhdyshenkilön nimeäminen kuuluvat hoidosta vastaavalle taholle. Terveydenhuollon kuntoutussuunnittelemia koskevissa tutkimuksissa on noussut esille tarve kehittää ja terävöittää kuntoutussuunnitelmia ja varmistaa kuntoutujan, tarvittaessa myös hänen läheistensä, osallisuus suunnitelman tekemisessä (Nikkanen 2010; Järvikoski 
ym. 2009). Kuntoutussuunnitelmat eivät aina vastaa hyvän kuntoutuskäytännön mukaisia suosituksia, ja kuntoutuksen yhdyshenkilö on jäänyt suunnitelmista nimeämättä (Paltamaa ym. 2011).

Kuntoutuksen tarpeen tunnistamisen ja kuntoutusprosessin käynnistämisen kannalta keskeinen ammattiryhmä ovat terveydenhuollossa lääkärit ja ikääntyneiden palveluissa palveluohjaajat. Lääkäreille tehdyssä kyselyssä todetaan, että enemmistö vastanneista koki kuntoutuspalveluja koskevan tiedon olevan vaikeasti löydettävissä. Lääkärit kaipasivat lisää tietoa kuntoutuksesta kaikille kuntoutustoimijoille ja ehdottivat erityisten kuntoutuskoordinaattorien nimeämistä. Koordinaattorin toiminta parantaisi lääkärien mukaan kuntoutustarpeen ja kuntoutusmahdollisuuksien yhteen saattamista. (Shemeikka ym. 2013.)

Koukkari (2010) kartoitti tutkimuksessaan kuntoutujien kokemuksia kuntoutuksesta ja kuntoutumisesta. Kuntoutumiseen liittyvänä puutteena nousi esiin kuntoutusprosessiin liittyvän ohjauksen ja neuvonnan vähäisyys tai puuttuminen sekä epävarmuus siitä, kuka ajaa kuntoutujan asioita tai keneen kuntoutuja voi ottaa yhteyttä ongelmatilanteissa. Kuntoutusta koordinoivan henkilön puuttuessa tätä tehtävää joutui hoitamaan omainen.

Sosiaali- ja terveysministeriö sekä työ- ja elinkeinoministeriö toteuttivat vuosina 20132015 mittavan osatyökykyisten työllistymisen edistämiseen liittyvän hankkeen. Osatyökykyiset työssä toimintamallin (OSKU) keskeinen työrukkanen on työkykykoordinaattori, joka toimii TE-hallinnossa, työpaikoilla, työterveyshuollossa tai oppilaitoksessa. Työkykykoordinaattorimallin on todettu lisäävän osatyökykyisten osallisuutta muutosprosessissa. Hankeraportissa esitetään yhteistyötä eri palvelusektoreiden välillä ja hyväksi havaitun mallin laajentamista. (Nevala ym. 2015.) Hankkeen tuloksena on käynnistetty työkykykoordinaattorikoulutus. (STM 2015.)

Kuntoutusohjausta lähellä oleva käsite on palvelu- tai asiakasohjaus. Palveluohjaus on asiakkaan palvelukokonaisuuden koordinointityötä, jolla edistetään yhteistoimintaa eri or- ganisaatioiden ja hallinnonalojen välillä. Palveluohjaukseen sisältyy sekä asiakaslähtöinen asiakastyö (case management) että palveluiden yhteensovittaminen organisaatioiden tasolla (service coordination). (Hänninen 2007). Palveluohjausta tehdään myös sosiaalihuoltolain (L1301/2014) ja vanhuspalvelulain (L980/2012) mukaisessa palvelutarpeen arvioinnissa, ohjauksessa ja seurannassa.

\section{Kuntoutuksen ohjaajan (AMK) koulutus ja osaaminen}

Kuntoutuksen ohjaajia (AMK) on koulutettu vuodesta 1997 lähtien, ja tällä hetkellä koulutusta järjestävät Jyväskylän ja Satakunnan ammattikorkeakoulut. Koulutuksen aloittamisen lähtökohtina olivat USA:ssa ja joissakin Euroopan maissa hyväksi koetut "case manageri" (palveluohjaaja) -tyyppiset koulutukset, joiden todettiin vaikuttavan kuntoutuksen tehostumiseen, kehittämiseen ja yhteiskunnallisten kulujen hillitsemiseen. (Kuntoutuksen suunnittelun ja ohjauksen suuntautumisvaihtoehdon opetussuunnitelma 1997.) Koulutusta ovat vuosien varrella kehittäneet kansalliset koulutuslinjaukset ja vuonna 2003 ilmestynyt Suomen Kuntaliiton kuntoutusohjausnimikkeistö. Myös kansainväliset laatuvaatimukset (EQF 6) ovat vaikuttaneet koulutusohjelman, nykyisen tutkinto-ohjelman, suunnittelutyöhön. Muuttuvat alueelliset tarpeet ja ammattikorkeakoulujen omat painopistealueet ovat myös olleet vaikuttamassa koulutusten kehitykseen.

Kuntoutuksen ohjaajan (AMK) koulutus on laajuudeltaan 210 opintopistettä. Tutkinto rakentuu perus- ja ammattiopinnoista, harjoittelusta, opinnäytetyöstä ja vapaasti valittavista opinnoista. Opiskelu on käytännönläheistä ja aikaisemmin hankittu osaaminen huomioidaan henkilökohtaisissa opintosuunnitelmissa. Koulutuksessa on mahdollista syventää ammatillista osaamistaan kuntoutuksen ohjauksen eri alueilla harjoittelujen, projektien, hankkeiden ja opinnäytetyön kautta. (Kuntoutuksen ohjaajan (AMK) tutkinto-ohjelmat 2015, Kuntoutusohjaaja koulutuksen opetussuunnitelma 2016-2017.) Koulutuksen 
opetussuunnitelmat (JAMK ja SAMK) ovat sisällöllisessä vertailussa ja osaamistavoitteissa hyvin lähellä toisiaan. Koulutuksen toteutuksessa korkeakoulujen välillä on jonkin verran eroja korkeakoulujen omien painotusten ja alueellisten lähtökohtien mukaan.

Ammattikorkeakoulusta valmistuneita kuntoutuksen ohjaajia on noin 600 , ja heitä toimii kaikilla kuntoutuksen sektoreilla; toimintakyvyn, ammatillisen, sosiaalisen sekä kasvatuksellisen kuntoutuksen tehtävissä. Kuntoutuksen ohjaajaksi valmistuneet toimivat työelämässä monilla kymmenillä eri ammattinimikkeillä. He ovat työllistyneet muun muassa erikoissairaanhoitoon, ammatilliseen kuntoutukseen, vammaispalveluihin, kuntouttavaan työtoimintaan, kehitysvamma-, päihde- ja mielenterveyskuntoutujien asumispalveluihin tai työtoiminnan ohjaukseen, kuntoutuskeskuksiin, Kelaan ja työterveyshuoltoon (Laine \&t Nappa 2014; Renfors 2014).

Kuntoutuksen ohjaajan (AMK) tutkintokoulutuksessa kuntoutus nähdään laajasti, ihmisen kaikkiin elämänalueisiin liittyvänä monitieteisenä ja -alaisena toimintana, jossa hyödynnetään kansainvälistä toimintakyvyn, toimintarajoitteiden ja terveyden viitekehystä (ICF). Kuntoutus voi käynnistyä lääketieteellisten kriteerien lisäksi suorituksiin, osallisuuteen, ympäristötekijöihin tai yksilöllisiin (vrt. ICF) tekijöihin liittyvien rajoitteiden pohjalta (Pikkarainen 2015). Kuntoutuksen kohteena tulee olla aina myös yksilön ympäristö, ei vain yksilö irrallisena toimenpiteiden kohteena. (Järvikoski 2013.)

Ohjaus voidaan ymmärtää ammatteihin liittyvänä yleisenä ohjaustyönä, tai ohjausta voidaan tarkastella erityisosaamisena (Vänskä 2012). Kuntoutuksen ohjaaja (AMK) -koulutus tuottaa ohjauksen erityisosaamista, joka ei sisälly yhtä laajana osaamisena muihin kuntoutusalan koulutuksiin. Kuntoutusohjaus ei ole terapiaa, mutta hyvä ohjauskohtaaminen sisältää kuntoutujaa arvostavan läsnäolon, kuuntelun taidon ja kuntoutujan voimaantumista edistävän vuorovaikutuksen. Ohjaukseen liittyvät erityispiirteet muodostuvat ohjauksen merkityksestä, kuntoutujan ja kuntoutujan toimintakontekstin ymmärtämi- sestä sekä motivoivasta ohjausosaamisesta ja ohjauksen kontekstin huomioimisesta. Pelkkä kuntoutusjärjestelmän, -lainsäädännön ja -palvelujen tunteminen ei riitä. Kuntoutuksen ohjaajan tulee ymmärtää myös kuntoutujan muutos- ja oppimisprosessia ja osata soveltaa ohjaustaitojaan muuttuvissa tilanteissa ja moniammatillisissa verkostoissa.

Valmistuvan kuntoutuksen ohjaajan (AMK) osaaminen esitetään opetussuunnitelmissa kompetensseina (pätevyyksinä, osaamisina). Tutkinto-ohjelman tuottamat osaamiset jaotellaan sosiaali- ja terveysalan yhteisiin ja ammattispesifisiin osaamisiin (JAMK) tai perus- ja ammatillisiin opintoihin (SAMK). Yhteisiä osaamisia ovat muun muassa kansainvälisyys-, yrittäjyys-, viestintä- ja tiedonhallintaosaaminen. Kuntoutuksen ohjaajan (AMK) tutkinto-ohjelman ammattispesifisissä osaamistavoitteissa on kuvattu kuntoutuksen ohjaajan keskeiset osaamiset (taulukko 1).

Korkeakoulutuksen merkittävimmät muutosvoimat seuraavien vuosien aikana ovat oppimisen muutos, digitalisaatio, kansainvälisyys, yrittäjyys, julkisen sektorin uudet toimintamallit sekä korkeakoulurakenteiden muutos (Halttunen 2015). Tämä tulee näkymään selkeästi myös kuntoutuksen ohjauksen koulutuksessa tulevaisuudessa.

\section{Kuntoutuksen ohjaajasta "kopin ottajaksi"}

Kuntoutuksen ohjaus on aina tähdännyt yli sektorirajojen tapahtuvaan koordinoituun toimintaan, joten sosiaali- ja terveydenhuollon järjestämistä koskevan mallin kehittämisessä ja toteuttamisessa kuntoutuksen ohjauksella on paikkansa. Uudessa mallissa tarvitaan uudenlaisia osaamisia, jolloin henkilöstön rekrytointivaiheessa olisi pysähdyttävä kysymään, millaista ajankohtaista tai täydentävää osaamista tarvitaan uutta työntekijää valittaessa, ei siis, mitä vanhaa virkaa tai työpaikkaa ollaan täyttämässä. Kuntoutuksen ohjauksen laaja-alaisella osaamisella voidaan uudessa sote-mallissa olla jalkauttamassa maakunnallisia uudenlaisia kuntoutuksen ja ennen kaikkea kuntoutumisen palveluita. 


\begin{tabular}{|c|c|}
\hline $\begin{array}{l}\text { Kuntoutuksen } \\
\text { asiakastyön } \\
\text { osaaminen }\end{array}$ & $\begin{array}{l}\text { - Tuntee kuntoutuksen kohderyhmät ja asiakkuudet } \\
\text { - Toimii ohjaustyössään kuntoutujalähtöisesti vahvistaen kuntoutujan } \\
\text { osallisuutta } \\
\text { - Hallitsee dialogisen vuorovaikutus- ja yhteistyösuhteen ja tukee } \\
\text { kuntoutujaa ja hänen läheisiään kuntoutusprosessin aikana }\end{array}$ \\
\hline $\begin{array}{l}\text { Kuntoutuksen } \\
\text { palvelujärjestelmä- } \\
\text { osaaminen }\end{array}$ & $\begin{array}{l}\text { - Hyödyntää tietoa kuntoutuksen palvelujärjestelmästä, palveluista, } \\
\text { toimintamuodoista ja toimijoista } \\
\text { - Osaa soveltaa ohjaustyössään kuntoutuksen lainsäädäntöä ja muuta } \\
\text { ohjeistusta kuntoutusmahdollisuuksia arvioitaessa } \\
\text { - On selvillä kuntoutustoiminnan vastuunjaosta, kustannuksista ja } \\
\text { rahoituskanavista } \\
\text { - On selvillä kuntoutuksen asemasta ja merkityksestä kansallisesti ja } \\
\text { kansainvälisesti }\end{array}$ \\
\hline $\begin{array}{l}\text { Kuntoutustarpeiden } \\
\text { ja -mahdollisuuksien } \\
\text { arviointiosaaminen }\end{array}$ & $\begin{array}{l}\text { - Ymmärtää ja osaa tunnistaa erilaisia kuntoutustarpeita aiheuttavia } \\
\text { tekijöitä yksilö-, yhteisö- ja yhteiskuntatasolla } \\
\text { - Osaa arvioida laaja-alaisesti kuntoutujan työ-ja toimintakykyä ja arjessa } \\
\text { - Selviytymistä, erityisesti suorituksia, osallisuutta ja ympäristöä } \\
\text { - Osaa arvioida kuntoutumisen tarpeita, odotuksia ja kuntoutus- } \\
\text { mahdollisuuksia } \\
\text { - Käyttää näyttöön ja hyviin toimintakäytäntöihin perustuvia menetelmiä } \\
\text { - Selvittää kuntoutujan kuntoutukseen liittyvät etuudet ja sosiaaliturvan }\end{array}$ \\
\hline $\begin{array}{l}\text { Ohjaus- ja } \\
\text { opetusosaaminen }\end{array}$ & $\begin{array}{l}\text { - Osaa käyttää ja soveltaa erilaisia ohjausmenetelmiä kuntoutusprosessin } \\
\text { vaiheissa tarkoituksenmukaisesti, eettisesti ja tavoitteellisesti } \\
\text { - Valmentaa kuntoutujaa ottamaan vastuuta kuntoutumisestaan } \\
\text { - Motivoi, ohjaa, opettaa ja tukee kuntoutujaa ja hänen sosiaalista } \\
\text { verkostoaan kuntoutumisprosessissa } \\
\text { - Ohjaa kuntoutujaa käyttämään tarkoituksenmukaisia palveluja } \\
\text { - Osaa toimia kouluttajana ja asiantuntijatehtävissä }\end{array}$ \\
\hline $\begin{array}{l}\text { Kuntoutuksen } \\
\text { suunnittelu- ja } \\
\text { johtamisosaaminen }\end{array}$ & $\begin{array}{l}\text { - Suunnittelee kuntoutumisprosesseja yhdessä asiakkaan ja } \\
\text { moniammatillisen asiantuntijatyöryhmän kanssa } \\
\text { - Osaa laatia hyvän kuntoutuskäytännön mukaisen kuntoutus- } \\
\text { suunnitelman moniammatillisesti } \\
\text { - Arvioi ja edistää kuntoutuksen ja kuntoutusohjauksen laatua ja } \\
\text { vaikuttavuutta } \\
\text { - Omaa taloudellista, hallinnollista ja työnjohdollista osaamista } \\
\text { - Suunnittelee ja toteuttaa erilaisia projekteja }\end{array}$ \\
\hline $\begin{array}{l}\text { Moniammatillinen } \\
\text { yhteistyöosaaminen }\end{array}$ & $\begin{array}{l}\text { - Valmentaa kuntoutujaa moniammatilliseen yhteistyöhön } \\
\text { - Käynnistää ja koordinoi monialaista ja -ammatillista yhteistyötä ja } \\
\text { toimii erilaissa kuntoutusverkostoissa } \\
\text { - Osaa arvostaa ja hyödyntää työssään kuntoutuksen moniammatillista } \\
\text { toimijaverkostoa } \\
\text { - Käyttää moniammatillisen yhteistyön menetelmiä }\end{array}$ \\
\hline $\begin{array}{l}\text { Työelämän } \\
\text { kehittämisosaaminen }\end{array}$ & $\begin{array}{l}\text { - Tunnistaa kuntoutus- ja kuntoutumisprosesseissa kehittämishaasteita ja } \\
\text { osaa kehittää toimintaa itsenäisesti tai osana moniammatillista tiimiä } \\
\text { - Omaa valmiudet kuntoutuksen ohjauksen ja palvelujen kehittämiseen } \\
\text { - Tukeutuu tutkittuun tai näyttöön perustuvaan tietoon kehittämistyössään } \\
\text { - Kehittää omaa ammatillista osaamistaan }\end{array}$ \\
\hline
\end{tabular}


Sote-uudistuksen käynnistyessä kuntoutuksen kenttä erilaisine lakeineen, ohjeistuksineen, toimintakäytänteineen ja ammatteineen sekä työn perusteineen on hajanainen. Kuntoutusasiakas joutuu kärsimään hajanaisuudesta paitsi kuntoutustarpeiden tunnistamisen vaiheessa ja kuntoutuspolun katkoksissa, myös seikkaillessaan monialaisten kuntoutuspalveluiden viidakossa etsimässä itselleen sisällön, kuntoutusmuodon ja käytettävien menetelmien suhteen tarkoituksenmukaisia palveluita. Kuntoutuksen palveluja ei koordinoida suunnitelmallisesti yksityisen, julkisen ja kolmannen sektorin kesken.

Kuntoutukseen tarvitaan "kopin ottaja", joka koordinoi kuntoutujan hoitoketjun toteutumista (Piirainen \&t Sjögren 2015). Koukkari (2010) haastaa kuntoutuksen kehittäjät ja toimijat tunnistamaan kuntoutusprosessin ohjaukseen liittyvät erityiskysymykset ja kehittämään ohjaustoimintaa. Kuntoutuksen ohjaajan (AMK) tutkinto vastaa jo nykyisine sisältöineen hyvin tutkijoiden esittämään kuntoutuskoordinaattorin tai "kopin ottajan" tehtävän haasteeseen (Piirainen \& Sjögren 2015; Järvikoski 2013; Shemeikka ym.2013; Koukkari 2010).

\section{Kuntoutuksen ohjaajan (AMK) koulutus - opiskelijoiden kokemuksia}

"Kuntoutuksen ohjaajan (AMK) opintojen ensimmäisenä vuonna rakentuu pohja moniammatillisen yhteistyön ja asiakaslähtöisen toiminnan valmiuksille. Moniammatillisissa tiimeissä opiskelu auttaa tarkastelemaan asioita useasta näkökulmasta. Kuntoutuksen ohjaaja -opiskelijalle kuntoutus toimintaympäristöineen näyttäytyy aluksi erittäin laajana kokonaisuutena. Tulevaa omaa roolia sosiaalija terveysalan palveluissa on aluksi vaikea hahmottaa, kun muiden koulutusohjelmien opiskelijoiden ammatillinen näkökulma ja identiteetti tuntuvat muodostuvan jo varhain. Itse koen tämän haastavan vaiheen läpikäymisen vahvuutena, koska samaan aikaan opinnoissa työstetään sitä, mitä asiakaslähtöisyys on. Vähitellen kuntoutuksen ohjaaja -opiskelijalle muodostuu kokonaisvaltainen käsitys kuntoutusprosessista: ei ole pelkästään tärkeää se mitä minulla on kuntoutujalle tarjota, vaan huomioida se, mistä kuntoutuja hyötyisi ja miten me yhteistyössä eri palveluiden ja ammattiryhmien kanssa voimme vastata kuntoutujan tarpeisiin. Tämä on myös se näkökulma, jolle opintojen edetessä rakentuu kuntoutuksen ohjauksen ammatillisia valmiuksia, tietoa ja toimintamalleja, jotka konkretisoituvat käytännössä työelämälähtöisten projektien ja harjoittelun kautta.” (Lasse Rantala, päiväkoulutus, JAMK.)

"Tulin opintoihini lääkinnällisen kuntoutuksen kentältä yli 20 vuoden työkokemuksella vahvojen kuntoutuksen asiantuntijoiden moniammatillisesta tiimistä. Opintoja tarvitsemme juuri tässä sote-myllerryksen tiimellyksessä, jotta kuntoutuksellinen ote säilyy ja vahvistuu. Toiminta- ja työkyvyn arviointi -kurssilla asiakaslähtöisyys oli keskiössä, samoin ICF:stä ja GAS:sta opitut tiedot ja taidot. Kuntoutuksen ohjauksen prosessien ja työmenetelmien avulla olen saanut kuntoutussuunnitelmien laadintaan valtavasti tietoa. Asiakaslähtöinen kuntoutusohjaus toteutuu varmasti näiden ohjeiden perusteella. Harjoittelussa olen tutustunut laajasti kuntoutuksen monimuotoisuuteen: ammatilliseen, kasvatukselliseen ja psykiatriseen kuntoutukseen esimerkiksi työvoiman palvelukeskuksessa, päiväkodissa lasten kasvatuksellisessa kuntoutuksessa ja psykiatrisessa monimuotoyksikössä. Kuntoutuksen suunnittelun ja johtamisen harjoittelussa perehdyin keskussairaalan kuntoutukseen ja kuntoutussuunnittelijan työhön. Verkostotyö ja uudet yhteistyökumppanit ovat tärkeitä kuntoutusohjaukseen kuuluvia asioita, jotka ovat opintojen avulla saaneet uuden painoarvon." (Marianne From, monimuotokoulutus, JAMK.) 
Merja Koivuniemi, KM, lehtori, Satakunnan ammattikorkeakoulu

Teppo Karapalo, TtM, lehtori, Jyväskylän ammattikorkeakoulu

Pirjo Walden, THM, lehtori, Jyväskylän ammattikorkeakoulu

Aila Pikkarainen, THM, KM, lehtori, Jyväskylän ammattikorkeakoulu

\section{Lähteet}

Halttunen J (2015) Jyväskylän ammattikorkeakoulun lukuvuoden 2015-2016 avaus. http://www. jamk.fi/fi/Tapahtumat/avajaiset/halttunen-puhe/ 17.1.2016.

Hänninen K (2007) Palveluohjaus. Asiakaslähtöistä täsmäpalvelua vauvasta vaariin. Stakesin raportteja 20.

Järvikoski A (2013) Monimuotoinen kuntoutus ja sen käsitteet. Sosiaali- ja terveysministeriön raportteja ja muistioita 43, Helsinki.

Järvikoski A, Hokkanen L, Härkäpää K (toim.) (2009) Asiakkaan äänellä. Odotuksia ja arvioita vaikeavammaisten lääkinnällisestä kuntoutuksesta. Kuntoutussäätiön tutkimuksia 80, Helsinki.

Koukkari M (2010) Tavoitteena kuntoutuminen. Kuntoutujien käsityksiä kokonaisvaltaisesta kuntoutuksesta ja kuntoutumisesta. Akateeminen väitöskirja. Lapin Yliopisto. Yhteiskuntatieteiden tiedekunta, Rovaniemi.

Kuntoutuksen ohjaajan ja ohjauksen suuntautumisvaihtoehdon opetussuunnitelma 1997. Kuntoutusalan koulutusohjelma. Jyväskylän ammattikorkeakoulu.

Kuntoutuksen ohjaajan (AMK) tutkinto-ohjelma 2015. Jyväskylän ammattikorkeakoulu. http://opinto-oppaat.jamk.fi/fi/opinto-opas-amk/tutkintoohjelmat-ja-opintotarjonta/suomenkieliset-opsit/2015-2016/kuntoutuksen-ohjaaja/ 30.1.2016.

Kuntoutusasianneuvottelukunta (2015) Monialainen kuntoutus. Tilannekatsaus. Sosiaali- ja terveysministeriön raportteja ja muistiota 18, Helsinki.

Kuntoutusohjaaja koulutuksen opetussuunnitelma 2016-2017. Satakunnan ammattikorkeakoulu. https://samk.solenovo.fi/opsnet/disp/fi/ops_ KoulOhjSel/tab/tab/sea?koulohj_id=2300555\& ryhmtyyp=1 Etlukuvuosi=2384239\&stack=push 31.1.2016.

Kuntoutusohjausnimikkeistö 2010. Opas sisältöön ja käyttöön. Suomen Kuntaliitto.

Laine M, Nappa N (2014) JAMK:sta vuosina 2007-2013 valmistuneiden kuntoutuksen ohjaajien (AMK) työllistyminen, työelämässä koetut haasteet ja koulutuksen kehittämisideat. AMK-opinnäytetyö. http://urn.fi/URN:NBN:fi:amk-2014090113688 21.1.2016.

Nevala N, Turunen J, Tiainen R, Mattila-Wiro P (2015) Osatyökykyiset työssä toimintamallin (OSKU) toteutuminen ja hyödyt erilaisissa toimintaympäristöissä. Sosiaali- ja terveysministeriön raportteja ja muistiota 48, Helsinki.

Nikkanen P (2010) Vaikeavammaisten henkilön kuntoutussuunnitelman rakentumisen käytännöt. Sosiaali- ja terveysturvan selosteita 71. Kelan tutkimusosasto.

Paltamaa J, Karhula M, Suomela-Markkanen T, AuttiRämö I (toim.) (2011) Hyvän kuntoutuskäytännön perusta. Käytännön ja tutkimustiedon analyysistä suosituksiin vaikeavammaisten kuntoutuksen kehittämishankkeessa. Kelan tutkimusosasto.

Piirainen A, Sjögren T (2015) Jyväskylä 3.3.2015 Hyvinvointialojen dialogi kuntoutusalan koulutuksen tulevaisuus OKM 4.3.2015. http://www.minedu.fi/export/sites/default/OPM/Tapahtumakalenteri/2015/03/Hyvinvointialojen_dialogi_kuntoutus_liitteet/Kuntoutuksen_osaaminen_-tutkimuksen_tulokset_Tiivistelmx_Piirainen_ja_Sjxgren.pdf 30.1.2016.

Pikkarainen A (2015) Monialaisen kuntoutuksen uudistamistarpeet Keski-Suomessa. Keski-Suomen SOTE2020-hankkeen raportti 30.4.2015.

Renfors S-K (2014) Satakunnan ammattikorkeakoulusta kuntoutuksen ohjaaja (AMK) tutkinnon suorittaneiden työllistyminen, nykyinen työnkuva ja osaamisen haasteet. AMK-opinnäytetyö. http:// urn.fi/URN:NBN:fi:amk-2014112116231 6.1.2016.

Shemeikka R, Rinne H, Saares A, Parmanne P, Valkonen VP, Poutiainen E (2013) Lääkäreiden näkemyksiä kuntoutuksen haasteista ja kehittämisideoista. Kuntoutus 3, 20-30.

STM (2015) Työkykykoordinaattori osatyökykyisten tukena. Sosiaali- ja terveysministeriön verkkosivut.https://stm.fi/osatyokykyiset/osatyokykyiset/ tyokykykoordinaattori 30.1.2016.

Vänskä K (2012) Ohjauksen osaajat - miten he sen tekevät? Terveysalan ohjaajien käsityksiä ohjausosaamisesta. Väitöstutkimus. Jyväskylän ammattikorkeakoulun julkaisuja 132. 